\title{
Author Correction: An ecological network approach to predict ecosystem service vulnerability to species losses
}

\author{
Aislyn A. Keyes (1D, John P. McLaughlin, Allison K. Barner \& Laura E. Dee
}

Correction to: Nature Communications https://doi.org/10.1038/s41467-021-21824-x, published online 11 March 2021.

In the original version of the published article, two formulas in the "Robustness analysis" section of the Methods were incorrectly expressed as $R_{F}=\sum x(y)$ and $R_{E S}=\sum x(y)$. The formulas have now been correctly expressed as $R_{F}=\frac{\sum y(x)}{\max (x)}$ and $R_{E S}=\frac{\sum y(x)}{\max (x)}$.

In addition, the following sentence was added to the second paragraph of the "Robustness analysis" section for clarity: "Our species loss sequences did not all include the full species list, so we divided the AUC by the maximum proportion of species removed to scale robustness to the length of the sequence.". This has now been corrected in both the PDF and HTML versions of the Article.

Published online: 30 September 2021

(c) (i) Open Access This article is licensed under a Creative Commons Attribution 4.0 International License, which permits use, sharing, adaptation, distribution and reproduction in any medium or format, as long as you give appropriate credit to the original author(s) and the source, provide a link to the Creative Commons license, and indicate if changes were made. The images or other third party material in this article are included in the article's Creative Commons license, unless indicated otherwise in a credit line to the material. If material is not included in the article's Creative Commons license and your intended use is not permitted by statutory regulation or exceeds the permitted use, you will need to obtain permission directly from the copyright holder. To view a copy of this license, visit http://creativecommons.org/licenses/by/4.0/.

(c) The Author(s) 2021 